\section{PEREMPUAN AFGHANISTAN REPRESI DAN RESISTENSI}

Perempuan Afghanistan memiliki posisi yang sulit ketika harus berhadapan dengan konstruksi budaya patriarki, legitimasi ideologi, agama, serta tradisi dan budaya. Buku ini secara khusus memperlihatkan strategi naratif penulis dalam mengungkapkan represi yang dialami oleh perempuan Afghanistan dan dinarasikan melalui kedua teks, A Thousand Splendid Suns karya Khaled Hosseini dan My Forbidden Face: Growing Up Under the Taliban: A Young Woman's Story karya Latifa.

Pembahasan strategi naratif penulis dalam mengungkapkan represi yang dialami oleh perempuan Afghanistan dan dinarasikan melalui kedua teks dapat menjadi sumber ilmu bagi Anda yang sedang belajar kritik sastra. Untuk melengkapi pembahasan dipaparkan juga resistensi tokoh-tokoh perempuan terhadap aspek-aspek kultural dan religi.

Bagi Anda peminat kritik sastra dan pecinta karya-karya penulis diaspora Afghanistan, buku ini dapat menjadi buku referensi dan sumber informasi yang menambah cakrawala pengetahuan.

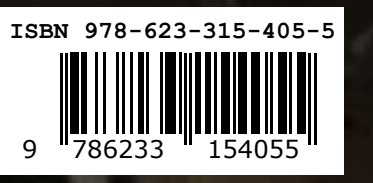

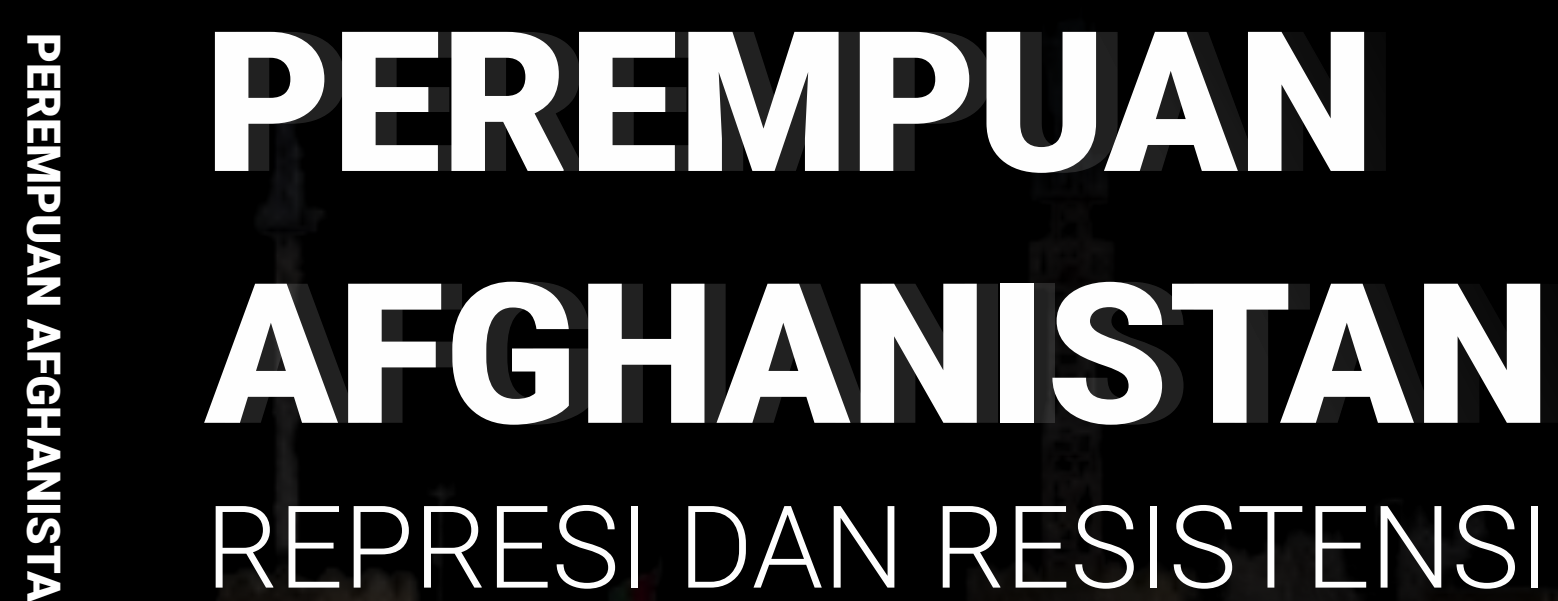

Dr. Hiqma Nur Agustina, M.Si., M.Hum.

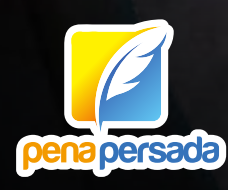


PEREMPUAN AFGHANISTAN

REPRESI DAN RESISTENSI

HIQMA NUR AGUSTINA

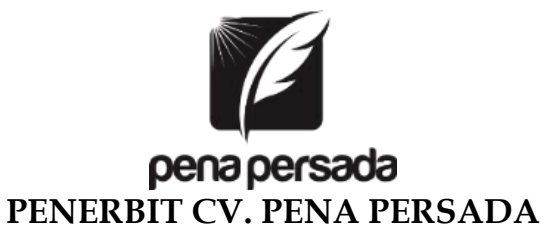




\title{
PEREMPUAN AFGHANISTAN \\ REPRESI DAN RESISTENSI
}

\author{
Penulis: \\ Hiqma Nur Agustina \\ ISBN: 978-623-315-405-5
}

\section{Editor:}

Wiwit Kurniawan

\section{Design Cover:}

Retnani Nur Briliant

\author{
Layout: \\ Nisa Falahia

\section{Penerbit CV. Pena Persada} \\ Redaksi:
}

Jl. Gerilya No. 292 Purwokerto Selatan, Kab. Banyumas

Jawa Tengah

Email: penerbit.penapersada@gmail.com

Website: penapersada.com Phone: (0281) 7771388

Anggota IKAPI

All right reserved

Cetakan pertama: 2021

Hak Cipta dilindungi oleh undang-undang. Dilarang memperbanyak karya tulis ini dalam bentuk apapun tanpa izin penerbit 


\section{KATA PENGANTAR}

Buku ini akan mengkaji dua karya sastra yang dikarang oleh diaspora Afganistan, yakni A Thousand Splendid Suns (2007) karya Khaled Hosseini dan My Forbidden Face: Growing Up Under the Taliban: A Young Woman's Story (2001), karya Latifa. Dua teks karya penulis diaspora Afghanistan ini merupakan sebuah representasi isu represi dan kekerasan yang mengemuka terhadap perempuan Afghan. Para perempuan Afghanistan memiliki posisi yang sulit ketika harus berhadapan dengan konstruksi budaya patriarki, legitimasi ideologi, agama, serta tradisi dan budaya yang turut serta mengokohkan represi yang terjadi.

Tujuan kajian dalam buku ini adalah untuk memperlihatkan strategi naratif penulis dalam mengungkapkan represi yang dialami oleh perempuan Afghanistan dan dinarasikan melalui kedua teks. Dengan demikian, dapat dijelaskan narasi yang lebih kuat di antara kedua penulis tersebut. Hal penting lainnya adalah mengungkap kekuasaan, dominasi, dan ketidaksetaraan gender dipraktikkan, direproduksi atau dilawan oleh teks. Representasi perempuan sebagai warga kelas dua yang terepresi oleh struktur masyarakat dalam kultur budaya patriarki yang berlandaskan Islam perlu juga dikaji untuk mendapatkan pemahaman yang komprehensif tentang upaya resistensi perempuan Afghanistan.

Selain itu, buku ini akan mengungkapkan resistensi tokohtokoh perempuan terhadap aspek-aspek kultural dan religi di dalam teks. Hal ini perlu dikaji untuk mengetahui potensi kedua aspek tersebut dalam memperkuat konstruksi gender yang tidak menguntungkan perempuan dari kacamata kedua penulis. Persamaan atau perbedaan keduanya dalam mengungkap peran gender dan budaya patriarki pada tokoh-tokoh di dalam teks juga yang ingin digali dalam penelitian ini.

Kajian dalam buku ini penting untuk melihat kondisi perempuan Afghanistan pada era 1978 - 2003. Sebuah masa yang diwarnai dengan berbagai represi sebagai akibat dari konstruksi kelas dan gender yang dilatarbelakangi oleh kultur patriarki. Dengan melakukan kajian ini, diharapkan dapat menjelaskan efek yang ditimbulkan dari berlangsungnya sistem patriarki dan 
konstruksi gender yang timpang, serta memberikan pemahaman baru akan pentingnya mengubah arah pemikiran dan pandangan tentang praktik-praktik konstruksi gender yang cenderung merepresi perempuan.

Buku ini diharapkan dapat memberikan sumbangan ilmu pengetahuan tentang khasanah Sastra Timur Tengah, khususnya Sastra Afghanistan. Dari data yang ditelusuri oleh penulis, belum diperoleh kajian yang membahas kedua teks yang ditulis oleh penulis laki-laki dan perempuan diaspora Afghanistan. Buku ini diharapkan juga dapat melahirkan kajian lain dari segi kajian terhadap dampak represi dari kacamata psikoanalis, mengingat korban utama dari konflik dan perang saudara adalah perempuan. Melalui kajian yang mengetengahkan kekhasan sebuah narasi yang banyak didasarkan pada latar belakang historis negara Afghanistan dan represi yang kental, upaya resistensi para perempuan Afghanistan dapat dilihat dan ditelaah dari kacamata penulis lain sehingga diharapkan lebih banyak kepedulian dan semangat untuk meneliti karya-karya sastra Afghanistan. Akhir kata, semoga karya ini bisa menjadi ilham dan bermanfaat bagi kita semua. Terima kasih.

Malang, 2 Mei 2021

Hiqma Nur Agustina 


\section{DAFTAR ISI}

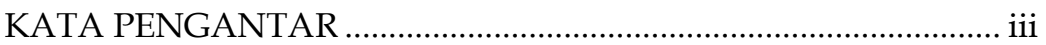

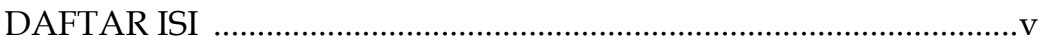

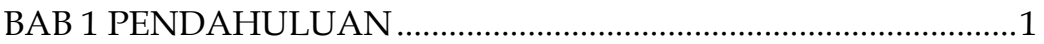

A. Kehidupan kaum perempuan Afghanistan......................... 1

B. Sastra Afghanistan dan Penulis Diaspora.............................. 4

C. Penulis Diaspora Afghan ....................................................10

D. Kajian atas Karya Khaled Hosseini dan Latifa ...................17

BAB 2 KONSEP NARATOLOGI DAN FEMINISME.........................28

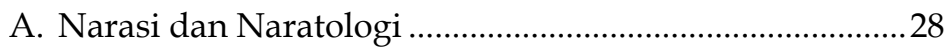

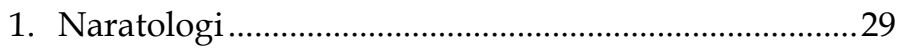

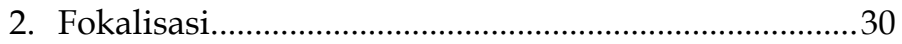

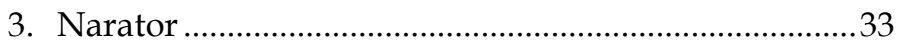

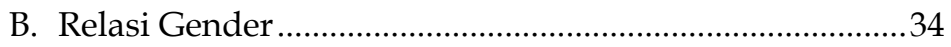

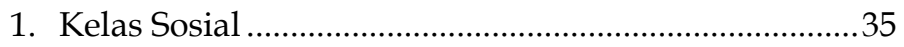

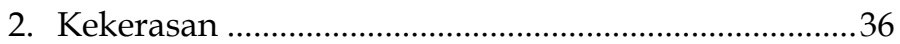

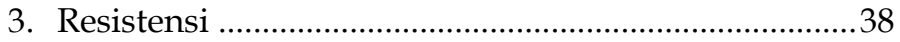

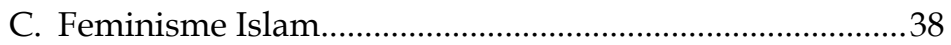

D. Feminisme Poskolonial.............................................................

BAB 3 FEMINISME ISLAM DAN FEMINISME

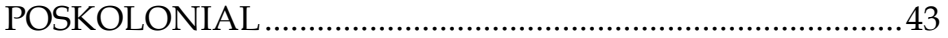

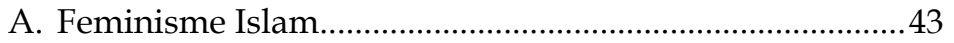

1. Kesetaraan Gender .............................................................

2. Kekerasan terhadap Perempuan ...................................58

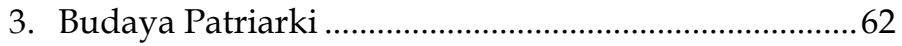

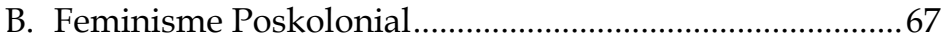

\section{BAB 4 REPRESI DALAM A THOUSAND SPLENDID SUNS}

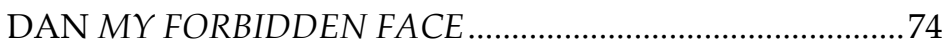

A. A Thousand Splendid Suns ...................................................75

1. Tubuh Perempuan Direduksi sebagai Alat

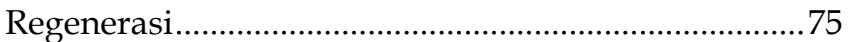

2. Perempuan sebagai Objek Laki-laki..............................79

3. Keberpihakan Hukum pada Laki-laki ............................87 


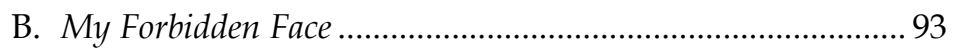

1. Pembatasan Ruang Gerak Perempuan.......................... 93

2. Hilangnya Hak untuk Berkarir dan Pembatasan Akses Pendidikan bagi Perempuan ............................ 104

C. Ambivalensi Fokalisator terkait Represi dalam Teks ... 107 BAB 5 RESISTENSI TOKOH PEREMPUAN AFGHANISTAN ... 111

A. A Thousand Splendid Suns.... 112

1. Melawan Stigma Perempuan sebagai Makhluk Kelas Dua 112

2. Melawan Jeratan Pernikahan Dini 117

3. Memberontak terhadap Kekangan Patriarki 119

B. My Forbidden Face

1. Melawan Penghapusan Hak Perempuan Beraktualisasi di Ranah Publik 122

2. Menolak Ketidakcermatan Penafsiran atas Tafsir/Hadis 126

C. Ambivalensi Fokalisator terhadap Resistensi dalam Teks 128

BAB 5 PENUTUP 131

DAFTAR PUSTAKA 135

TENTANG PENULIS 147 


\section{BAB 1 \\ PENDAHULUAN}

\section{A. Kehidupan kaum perempuan Afghanistan}

Afghanistan dikenal sebagai negara yang porak-poranda dilanda perang, baik perang yang disebabkan oleh penaklukan dari kerajaan lain di masa Sebelum Masehi (SM) hingga invasi negara-negara lain di awal abad ke-19. ${ }^{1}$ Afghanistan hingga sekarang tidak pernah damai karena selalu diincar oleh beberapa negara untuk dijadikan bagian dari negara mereka. Tujuan dari penaklukan di masa Sebelum Masehi berkaitan dengan keinginan para raja untuk menjadikan Afghanistan sebagai bagian dari wilayahnya, sedangkan invasi yang dilakukan oleh negara-negara lain dipicu oleh kepentingan politik internal dalam negeri yang dengan sengaja mengundang kekuatan asing untuk masuk dan mengintervensi (Maulani, 2002). Kondisi tersebut diperparah oleh konflik yang berkepanjangan sebagai akibat dari perang saudara dan pertikaian antar-etnis hingga kemunculan rezim Taliban (BBC Indonesia, 2009).

Perempuan Afghanistan pertama kali diberikan hak untuk memilih pada tahun 1919, hanya setahun setelah perempuan di Inggris diberi hak memilih dan setahun sebelum para wanita di Amerika Serikat diizinkan untuk memilih. Pada 1950-an, tidak ada keharusan memakai purdah (Burqa) bagi kaum perempuan Afghan. Selanjutnya, pada tahun 1960 konstitusi baru membawa persamaan ke banyak bidang kehidupan, termasuk partisipasi politik. Ketika Afghanistan mulai dilanda konflik di tahun 1970-an, hak-hak perempuan relatif stabil. Hak-hak perempuan Afghanistan semakin jauh berkurang selama kudeta dan pendudukan Uni Soviet di tahun 1970-an, dilanjutkan dengan konflik sipil antara kelompokkelompok Mujahidin dan pasukan pemerintah di era 1980-an

1 Tercatat ada tiga negara yang pernah menginvasi Afghanistan, yakni: Inggris, Uni Sovyet, dan Amerika Serikat. 
dan 1990-an, serta berpindah pada Taliban yang mengambil alih kekuasaan pemerintahan (Mosadiq dalam Amnesty International UK, 2014). Pada Juni 1978, kaum perempuan Afghan masih dapat mengenakan pakaian modern seperti di Barat, yakni blus dan rok pendek yang menjadi kekhasan gaya berpakaian era 1970-an atau mengenakan pakaian khas suku Pashtun yang lebar tanpa penutup kepala (Sarkar dalam CNN, 2015). Tidak ada pembatasan atau larangan bagi kaum perempuan Afghan dalam berpakaian di tahun tersebut sehingga kehidupan yang nyaman dan normal benar-benar mereka rasakan.

Menurut Rostami-Povey dalam Afghan Women Resistance and Struggle in Afghanistan and diasporic communities (2004-2005), selama periode invasi Uni Soviet ke Afghanistan di tahun 1978 dan setelah perang saudara (1992-1996) serta periode Taliban (1996-2001), tujuh juta orang Afghanistan dipaksa meninggalkan negara mereka dan hidup sebagai diaspora, terutama di Iran, Pakistan dan beberapa negara tetangga dan juga di Barat. Kehidupan baru di negara tujuan menuntut penduduk Afghanistan untuk dapat beradaptasi dengan cepat karena tidak memiliki pilihan yang lebih baik.

Horia Mosadiq ${ }^{2}$ (2013) menyatakan kehidupan perempuan Afghan memiliki kebebasan sebelum invasi Uni Soviet di tahun 1978. Banyak perempuan yang berprofesi sebagai politikus, guru, profesor di universitas dan memiliki kehidupan sosial yang sangat baik. Kebebasan perempuan mulai berkurang ketika Uni Soviet menginvasi Afghanistan dan mendukung kelompok Mujahidin. Kelompok Mujahidin melakukan banyak pembunuhan dan pemerkosaan terhadap perempuan setelah Uni Soviet keluar dari Afghanistan dan mulai mengambil alih kekuasaan pemerintahan. Pergolakan semakin bertambah parah ketika terjadi perebutan kekuasaan

2 Horia Mosadiq adalah seorang saksi perempuan Afghan yang bekerja di Amnesty International UK. Mosadiq menyaksikan segala bentuk kekacauan sejak invasi Uni Uni Sovyet, perang saudara antara kelompok Mujahidin hingga rezim Taliban mengambil alih pemerintahan di Afghanistan. 
antara Mujahidin dan Taliban yang kemudian dimenangkan oleh Taliban.

Taliban muncul di awal 1990-an di Pakistan Utara setelah tentara Uni Soviet ditarik mundur dari Afghanistan. Sebagai gerakan yang didominasi oleh suku Pashtun, Taliban mulai dikenal di Afghanistan pada September 1994. Kelompok ini pertama muncul dari pertemuan resmi keagamaan, dibiayai oleh Saudi Arabia yang mengajarkan aliran Islam Sunni. Jika berkuasa, janji Taliban - di wilayah Pashtun yang terletak antara Pakistan dan Afghanistan - adalah jika berkuasa akan menciptakan kembali perdamaian dan keamanan serta menerapkan Syariah Islam untuk menata kembali Afghanistan.

Taliban adalah kelompok pasukan Mujahidin yang menamakan diri sebagai pelajar sekolah agama. Taliban tidak hanya menduduki ibukota, tetapi juga menguasai nyaris seluruh Afghanistan. Kekuatan oposisi, dikenal sebagai Aliansi Utara, hanya bisa menguasai sebagian kecil wilayah utara Afghanistan (BBC Indonesia, 2009). Sebagian besar negara di dunia tidak mengakui rezim Taliban sebagai pemerintah sah Afghanistan. Berbagai aturan represif diterapkan Taliban setelah berhasil merebut Kabul. Banyak larangan atau dekrit yang diterapkan pada kaum perempuan Afghanistan, seperti menonton televisi, mendengarkan musik, menggunakan produk modern di katalog fashion, baju perempuan modern, gitar, catur, kartu ucapan, cat kuku dan perhiasan. Perintah larangan tersebut diumumkan pada jaringan televisi CNN pada 19 Juli 2001 oleh Mullah Mohammad Omar, Ketua Dewan Syariah tertinggi Taliban.

Sebelumnya rezim Taliban telah melarang menggambar hewan atau penulisan ayat-ayat Alquran di sembarang tempat. Sejak berkuasa dan memberlakukan syariat ${ }^{3}$ Islam, mereka berusaha agar rakyatnya melakukan aktivitas yang tidak jauh dari "mengingat Allah". Namun, pada perkembangan

${ }^{3}$ Syariat atau syariah adalah dua kata yang memiliki makna yang sama dan diambil dari bahasa Arab الثريعة. Syariah menurut istilah adalah teks-teks suci yang diturunkan Allah kepada Rasulullah, baik Al-Quran maupun As-Sunnah. 
selanjutnya aturan keagamaan jadi sangat tergantung pada interpretasi penguasa. Pemakaian lipstik hingga permainan gitar atau catur dilarang penguasa Taliban karena dianggap tidak sesuai dengan syariat Islam dan masuk dalam kategori "perbuatan maksiat".

Kehidupan kaum perempuan Afghanistan setelah rezim Taliban berkuasa menjadi semakin menderita terlebih sejak hak dan kemerdekaan untuk beraktivitas di ranah publik dicabut. Secara otomatis kaum perempuan Afghan hidup terpenjara di rumah. Segala aktivitas yang biasa dilakukan di ranah publik sudah tidak dapat lagi dilakukan. Apabila melanggar larangan Taliban, hukuman keras sudah menanti. Pemerkosaan dan kekerasan marak terjadi. Kaum perempuan Afghan dianiaya dengan mengatasnamakan hukum dalam setiap aspek kehidupan mereka sehari-hari (Mosadiq dalam Amnesty International UK, 2014).

\section{B. Sastra Afghanistan dan Penulis Diaspora}

Sastra Afghanistan didominasi karya puisi yang indah terdiri dari bait-bait panjang menjadi kekhasan para penyair besar di Afghanistan. Karya puisi ini menjadi ciri khas Afghanistan sebelum perang menghancurleburkan negara ini. Puisi dalam bahasa Farsi telah mendominasi sastra Afghanistan, meskipun bahasa lain juga turut memberikan andil. Mushaeras atau kompetisi puisi menjadi tradisi yang umum diselenggarakan. Afghanistan juga menjadi tempat kelahiran beberapa penyair besar, seperti Rabi'ah Balkhi penyair pertama dari Persia, penyair kerajaan Ghaznavid, serta Jami Herat dan Ali Sher Nava'i (Amazine, 2015). Karut-marut kondisi negara Afghanistan, yang sebelum perang dikenal dengan keragaman budaya, etnis, dan tradisi juga turut membawa perubahan dalam bidang sastra. ${ }^{4}$

${ }^{4}$ Afghanistan terdiri dari berbagai macam etnis yang membawa keragaman mereka sendiri dan menyumbang kepada kekayaan budaya Afghanistan dalam artikel "Budaya dan Tradisi Afghan". Tautan: http://www.amazine.co/22584/ ketahui-budaya-bahasa-dan-tradisi-afghanistan/ diunduh pada 23 April 2015. 
Kondisi politik yang tidak stabil dan perang yang menghancurleburkan Afghanistan membuat banyak penduduk melakukan eksodus ke berbagai negara. Keberadaan para pelarian di berbagai negara serta aktifnya mereka menceritakan kisah tentang Afghanistan membawa dampak yang besar. Penduduk Afghanistan yang tinggal di manca negara menggunakan bahasa asing, seperti Inggris dan Perancis, dan tidak lagi menggunakan bahasa Dari atau Pashto, bahasa ibu mereka. Ciri khas Afghanistan tetap melekat dalam narasi yang ditulis walaupun sudah berada jauh dari tanah kelahiran, seperti ruang, tema yang diusung, unsur politik, dan keturunan yang mengikat para penduduk Afghanistan yang tinggal di luar negeri ini. ${ }^{5}$ Dengan menggunakan bahasa Inggris, para penulis diaspora ini lebih mudah dalam mempublikasikan kisah tentang negaranya pada publik internasional dengan tema-tema, seperti represi, kerinduan pada negara asal, konflik dan perang saudara hingga dampak dari masifnya kekerasan yang dilakukan rezim Taliban pada penduduk Afghanistan.

Kesusasteraan Afghanistan juga dikenal dengan kekuatannya dalam tradisi penceritaan legenda dan cerita rakyat yang disampaikan dalam bahasa utama yang juga menjadi bahasa nasional Afghanistan, Dari dan Pashto. Selama Abad Pertengahan, banyak karya sastra ditulis tidak hanya dalam kedua bahasa nasional tersebut, namun juga ditulis dalam bahasa Turki dan Arab. Bahasa Dari merupakan bahasa dialek dari bahasa Persia yang digunakan di wilayah utara dan tengah Afghanistan, sedangkan penggunaan Pashto lebih menonjol di wilayah selatan. Selain dua bahasa tersebut, sebagian penduduk Afghanistan juga menggunakan bahasa lain seperti Uzbek, Balochi, dan Turkmen (Amazine, 2015).

Khushal Khan Khattak (1613-25 Februari 1689) adalah salah satu penyair Pashtun yang terkenal mempromosikan budaya dan tradisi Pashtun melalui puisi. Khattak adalah

${ }^{5}$ Karya-karya sastra yang diusung oleh para diaspora Afghan ini yang menjadi pokok kajian dalam penelitian ini, bukan pada karya-karya sastra yang menggunakan bahasa Dari atau Pashto. 
penyair pertama Afghanistan yang berusaha mempersatukan etnis Pashtun melawan kekuatan asing dan membentuk bangsa Afghanistan. Dia menulis banyak puisi dalam bahasa Pashto, dan sedikit dalam bahasa Persia. Khattak menulis lebih dari 45.000 puisi dan lebih dari 200 buku. Tema alam, agama, dan obat-obatan yang diusung oleh Khattak dalam beberapa bukunya, seperti Baz-nama, sebuah buku yang mengisahkan perburuan dengan menggunakan burung Elang; Swat-nama yang berisi deskripsi perjalanan ke Swat Valley yang indah; Fazl-nama merupakan sebuah buku pegangan untuk tugas keagamaan dan sosial; dan Tibb-nama merujuk pada sebuah buku tentang resep obat. Khattak dianggap sebagai Bapak Sastra Pashto dan penyair Afghanistan (Biddulph, 1890).

Penyair sekaligus sufi yang lahir di Balk (sekarang Afghanistan) yang sangat terkenal sampai saat ini, yakni Maulana Jalaluddin Rumi Muhammad bin Hasin al Khattabi alBakri atau dikenal dengan nama Jalaluddin Rumi atau Rumi (30 September 1207 AD-17 Desember 1273 AD). Kumpulan puisi Rumi yang berjudul al-Matsnawi al-Maknawi adalah sebuah revolusi terhadap Ilmu Kalam. Isi kumpulan puisi ini mengkritik langkah dan arahan filsafat yang cenderung melampaui batas, mengebiri perasaan, dan mengkultuskan rasio. Puisi Rumi memiliki ciri khas tersendiri. Melalui puisi, Rumi menyampaikan pemahaman atas dunia hanya mungkin dicapai lewat cinta dan menekankan Tuhan sebagai satusatunya tujuan. Ciri lain yang membedakan puisi Rumi adalah kecenderungan untuk menampilkan kisah. Kisah-kisah ini digunakan untuk menyampaikan pikiran dan ide. Rumi juga dikenal sebagai sosok legendaris dalam seni tari dan musik (Rahman, 2008).

Nama intelektual lainnya yang cukup berpengaruh dalam pengembangan sastra dan jurnalisme Afghanistan adalah Mahmud Beg Tarzi (23 Agustus 1865-22 November 1933). Karya pertamanya berjudul Sayahat-Namah-e-Manzum (Account of Journey) yang diterbitkan di Lahore. Tarzi juga dikenal sebagai orang yang memperkenalkan dasar jurnalisme di 
Afghanistan. Tarzi memperkenalkan gerakan modernis Afghanistan melalui penerbitan surat kabar pertama yang bertajuk Seraj-al-Akhbar. Surat kabar ini turut memainkan peranan penting dalam modernisasi dengan memberikan ruang bagi terbentuknya forum diskusi kecil, yang menjadi pencerahan bagi para generasi muda Afghan (Rahman, 2008).

Tarzi juga menerbitkan sebuah surat kabar untuk remaja, Seraj-al-Atfal (Children's Lamp). Selain di bidang jurnalisme, Tarzi adalah orang pertama yang memperkenalkan novel berbahasa Inggris di Afghanistan dan menerjemahkannya ke dalam bahasa Dari dan Pashto. Dia juga memberikan kontribusi dalam mengedit, menerjemahkan, dan memodernisasikan surat kabar Afghanistan. Banyak karya besar penulis Eropa diterjemahkannya, Around the World in Eighty Days (1873), Twenty Thousand Leagues Under the Sea (1870), The Mysterious Island (1874), International Law ${ }^{6}$ (dari Turki), dan the History of the Russo-Japanese War (1904). Hukum internasional adalah seperangkat peraturan yang umumnya dianggap dan diterima sebagai pengikatan hubungan antara negara dan antar negara. Ini berfungsi sebagai kerangka kerja untuk praktik hubungan internasional yang stabil dan terorganisir. Ketika tinggal di Turki dan Siria, Tarzi banyak melakukan pembacaan dan penelitian menggunakan sumbersumber sastra dan ilmiah Barat (Ruttig, 2011).

Tiga buah karya Tarzi tidak diketahui secara pasti tahun penerbitannya. Karya pertama Tarzi di Damascus berjudul The Garden of Learning dan berisi artikel pilihan tentang sastra, seni, wisata, dan hal-hal ilmiah. Buku kedua berjudul The Garden of Knowledge diterbitkan di Kabul dan diakhiri dengan sebuah artikel berjudul My Beloved Country, Afghanistan. Tulisan tersebut berisi kerinduan akan tanah kelahiran dan nostalgia akan kondisi iklim, pegunungan, dan gurun di Afghanistan. Pada tahun 1914, novel Tarzi Travel across Three Continents in Twenty-Nine Days diterbitkan. Banyak tulisan Tarzi diterbitkan setelah dia wafat (Ruttig, 2011).

${ }^{6}$ Https://www.eduspensa.id/hukum/ 
Cerita pendek dalam pengertian modern tidak memiliki sejarah panjang dalam literatur Dari-Persia di Afghanistan. Kisah pertama dalam literatur modern Afghanistan, yakni Jehad-e Akbar ditulis sekitar tahun 1919 oleh Mevlevi Mohammad Husain Panjabi. Setelah itu beberapa cerita lain yang ditulis oleh penulis lain diterbitkan di media umum pada masa itu. Akan tetapi tidak ada perempuan yang memiliki peran dalam proses ini sampai Mahga Rahmani (lahir sekitar tahun 1911) menjadi perempuan penulis cerita pertama di Afghanistan (Rajabe, 2014).

Tradisi penceritaan berupa puisi dilanjutkan oleh Abdul Bari Jahani (1948-2015), seorang penyair kontemporer terkenal yang menggunakan bahasa Pashto. Jahani mendapatkan gelar Sarjana Muda dari Fakultas Sastra, Universitas Kabul. Dia pernah bekerja untuk layanan Pashto Voice of America di Washington DC sebagai produser dan presenter dari tahun 1983 hingga pensiun pada tahun 2010. Jahani telah menerbitkan sekitar dua puluh buku. Sebagian besar terdiri dari puisi, tetapi beberapa diantaranya tentang sejarah dan sastra rakyat Pashto. Dia juga menulis lagu kebangsaan Afghanistan, yang disetujui oleh pemerintah pada tahun 2006. Salah satu judul puisi, "Pride". terdapat dalam kumpulan puisi Da Sabawoon Pa tama (Berharap Fajar) yang diterbitkan pada tahun 1999 (Maqsudi, 1996).

Seni mendongeng dengan teknik kuno terus berkembang di Afghanistan sebagai dampak dari buta huruf yang meluas. Cara kuno dengan menceritakan dongeng-dongeng melalui musik dan kata ucapan adalah bentuk seni yang sangat maju dan sangat dihargai. Penggunaan cerita rakyat telah menjadi alat yang menghubungkan masa lalu dengan masa kini dalam masyarakat Afghanistan. Cerita rakyat berkaitan dengan semua bagian kehidupan Afganistan dan sering mengajarkan nilainilai, keyakinan, dan perilaku tradisional yang dianggap sebagai hiburan utama rakyat Afghanistan (Rajabe, 2014). 
Selama awal penulisan cerita modern di Afghanistan pada tahun 1950-an dan 1960-an, tidak ada perempuan yang memiliki peran dalam dunia sastra. Akan tetapi, dengan perubahan politik selama dekade tersebut, yakni periode demokrasi, pembentukan media cetak dan penyiaran pribadi, pendirian Asosiasi Sastra Kabul, serta dibukanya kebebasan dan peluang bagi perempuan, perempuan mulai berpartisipasi di bidang sastra. Meskipun cerita dari para penulis perempuan ini tidak dapat menarik perhatian lebih banyak pembaca, hal itu adalah awal yang baik bagi perempuan untuk menghasilkan karya selanjutnya (Rajabe, 2014).

Selanjutnya, kemunculan tulisan-tulisan modern berhasil membawa penduduk Afghanistan untuk lebih dekat memahami perubahan yang terkait dengan dunia modern, terutama untuk memahami kehancuran negara akibat perang. Pada tahun 1972 Sayyid Burhanuddin Majruh menulis beberapa jilid novel klasik dengan kekhasan irama dari prosa tentang seorang musafir yang bergabung dengan orang-orang sebangsanya di pengasingan. Para musafir ini bertukar ide dan narasi dari zaman kuno ke zaman yang lebih mengedepankan konsep-konsep modern tentang akal, logika, sains, dan psikoanalisis. Selama invasi Uni Soviet di Afghanistan, tulisantulisan berfokus pada kekhawatiran akan aliran Islam yang mendua (Sunni dan Syiah) dan kebebasan. Perlawanan terhadap Uni Soviet terutama terjadi di Provinsi Paktia Pashto. Pada tahun 1983, Gulzarak Zadran menerbitkan Afghanistan the Land of Jihad: Paktiain Uprising Waves dalam bahasa Pashto. Sebuah lembaga bernama Afghanistan Historical Society dan Akademi Pashto menerbitkan majalah kesusateraan dan mendorong para penulis baru di akhir tahun 1983, meskipun kemudian terhenti karena peperangan terbaru mulai melanda (Rajabe, 2014).

Pada tahun 1990-an, setelah keberhasilan Revolusi Islam terjadi perang saudara dan keberadaan kelompok politik baru dengan nama Taliban, penulis perempuan dilarang, dan sebagai akibatnya mereka bermigrasi ke luar negeri. Selama 
dekade itu, situasi politik dan sosial di Afghanistan memunculkan pembatasan tambahan bagi perempuan untuk bekerja di bidang budaya. Oleh karena itu, sebagian besar penulis meninggalkan negaranya dan bermigrasi ke luar negeri, terutama ke Iran dan Pakistan. Migrasi ini mengarah pada penciptaan dan penguatan kelompok sastra di pengasingan (Rajabe, 2014).

Di masa Taliban berkuasa, para penulis juga menjadikan puisi sebagai sarana untuk menyampaikan ide atau gagasan kepada masyarakat. Puisi Taliban mencerminkan bahasa sebagai transformasi dari terminologi dan retorika formal Islam menjadi suara yang mendekati sensual dan pragmatis. Sebagai dampak, mereka lebih mengedepankan emosi daripada akal pikiran. Hasil puisi karya Taliban tidak didokumentasikan secara khusus mengingat fokus mereka hanya pada penerapan hukum Syariah pada penduduk Afghanistan (Widmark, 2011).

Dua nama penulis di luar Taliban menulis mengenai kisah trauma penduduk Afghanistan akan rezim Taliban yang kejam pada masa kekuasaan Taliban, antara lain, Zalmay Babakohi dengan karya The Idol's Dust dan Mohammad Hosseini Mohammadi dengan karyanya Dasht-e Laili. Dua karya tersebut berkisah tentang dua trauma nasional Afghanistan: Penghancuran patung Buddha di Bamiyan pada bulan Maret 2001 dan Pembantaian Dasht-e Laili pada bulan Desember di tahun yang sama (Rajabe, 2014).

\section{Penulis Diaspora Afghan}

Kondisi politik yang tidak menentu di Afghanistan mengakibatkan banyak penduduk mencari keselamatan ke negara lain. ${ }^{7}$ Kelompok yang melakukan migrasi ini selanjutnya menuliskan berbagai pengalaman hidup. Kemunculan para penulis diaspora Afghanistan pada era 2000an, baik laki-laki maupun perempuan, menjadi magnet bagi

7 Tidak kurang 78 negara di antaranya: Pakistan, Amerika Serikat, Prancis, Jerman yang menjadi negara-negara tujuan penduduk Afghanistan (Braakman, 2005). 
kelahiran sastra Afghanistan baru di dunia internasional. Keberadaan mereka di negara-negara Barat dan Amerika memberikan dampak persinggungan dengan sastra Barat sehingga memberikan pengaruh dalam bentuk penulisan. Terdapat pengayaan sastra Afghanistan dalam beberapa aspek. Pertama, bentuk yang mengalami perubahan dari puisi atau syair menjadi novel. Novel dipilih oleh para penulis untuk menuliskan kehidupan diaspora Afghanistan dan negara yang dituju. Kedua, bahasa yang digunakan. Para diaspora Afghanistan yang menulis dalam bahasa asing berhasil mengangkat cerita tentang Afghansitan. Yang terakhir adalah tema yang diangkat sangat menyapa dunia dan memiliki kekhasan sehingga dengan mudah dikenal oleh pembaca.

Tema yang diangkat oleh para penulis diaspora Afghanistan tersebut memperlihatkan keterkaitan dengan Afghanistan dalam banyak hal, seperti represi, budaya patriarki, konflik antar-etnis, perang saudara, invasi negara lain hingga kebrutalan dan kekejaman Taliban terhadap penduduk perempuan dan juga laki-laki Afghanistan. Walaupun banyak penulis diaspora dengan alasan keamanan sudah tidak lagi tinggal di Afghanistan, masih terdapat tarik-ulur secara naratif dengan dihadirkannya isu-isu khas Afghanistan sebagai medium untuk menceritakan berbagai represi yang dialami oleh perempuan Afghanistan sebagai latar (Matthews, 2010). Sebutan "Afghanistan, Negeri Yang Didera Perang" tak pelak juga menjadi dasar yang mengilhami kemunculan teks-teks yang menyajikan isu-isu fenomenal tentang perempuan (Hadibroto, 2002).

Penulis-penulis berikut hadir melalui karya-karya yang mengangkat berbagai isu dan konflik di Afghanistan. Dunia mengenal Farah Ahmedy yang kini bermukim di Amerika melalui karya The Other Side of the Sky. A Memoir (2005). Yang kedua adalah Nelofer Pazira yang tinggal di Kanada dan menulis sebuah novel A Bed of Red Flowers. In Search of My Afghanistan (2005). Sementara itu, Malalai Joya adalah seorang aktivis politik perempuan Afghanistan dengan karya 
autobiografi Raising My Voice: A Woman among Warlods: The Extraordinary Story of An Afghan who Dared to Raise Her Voice (2007).

Kajian ini berawal dari sebuah ketertarikan peneliti untuk melakukan sebuah kajian lanjutan dari permasalahan isu represi dan kekerasan yang dialami oleh kaum perempuan Afghanistan. Kajian dan riset yang mendalam melalui strategi naratif berupa fokalisasi, fokalisator dan narator penting dilakukan untuk melihat sikap kedua pengarang terhadap isu kekerasan dan represi dan diyakini menghasilkan temuan baru yang melengkapi hasil kajian dan penelitian tentang sastra Afghanistan sebelumnya.

Khaled Hosseini menghadirkan karya fiksi, sedangkan Latifa menulis dalam bentuk non-fiksi atau memoir yang sangat dekat dengan kenyataan. Upaya yang lebih kuat dalam menampilkan tokoh-tokoh perempuan yang mengalami represi dan melakukan resistensi dari kedua penulis menarik untuk dikaji. Dua genre yang berbeda dari karya kedua penuis ini juga menampilkan narasi yang berbeda pula, dan hal ini pula yang menjadikan dua korpus kajian ini layak untuk diteliti.

\section{Khaled Hosseini}

Salah satu nama penulis laki-laki Afghan yang sangat terkenal di kancah dunia internasional adalah Khaled Hosseini, seorang pria Afghan-Amerika. Tiga teks karya Hosseini adalah The Kite Runner (2001), A Thousand Splendid Suns (2007), dan And The Mountains Echoed (2013). Ketiga teks ini mengungkapkan persoalan isu represi yang terjadi dan dialami penduduk Afghanistan dalam kurun waktu 1978-2003.

Khaled Hosseini adalah penulis Afghan-Amerika yang memiliki latar belakang diaspora. Dia adalah putra seorang guru SMA dan diplomat yang dilahirkan di Kabul pada 1965. Ayah Hosseini ditugaskan ke Paris pada 1976. Saat keluarga Hosseini seharusnya kembali ke Afghanistan pada 1980, negeri tersebut sedang berada di dalam kekuasaan Soviet. Keluarga Hosseini mendapat suaka politik dari pemerintah Amerika Serikat, tepatnya di San Jose, California. Hosseini menuntut 
ilmu di Santa Clara University dan mengambil Jurusan Biologi, kemudian melanjutkan kuliahnya ke Jurusan Kedokteran pada 1989 di San Diego School of Medicine, California. Hosseini mulai berpraktik sebagai dokter umum sejak 1996, tiga tahun setelah lulus dari fakultas kedokteran.

Debut pertamanya sebagai penulis diawali dengan karya yang berjudul The Kite Runner (2001), yang mendapat banyak pujian dari penikmat sastra di seluruh dunia dan diterjemahkan ke dalam 42 bahasa. Kekuatan novel pertama Hosseini, The Kite Runner terletak pada gaya penceritaan dan mengusung permasalahan rasisme (Agustina, 2007). Novel pertama ini telah memenangi berbagai penghargaan di seluruh dunia dan menjadi buku terlaris sepanjang 2005. Berkat novel yang bertema persahabatan, kemanusiaan, dan universalisme ini, Hosseini menerima Humanitarian Award 2006 dari UNHCR, yang sekaligus mengangkat Hosseini sebagai Duta Kemanusiaan PBB untuk urusan pengungsi. ${ }^{8}$ Novel kedua Hosseini A Thousand Splendid Suns (ATSS) diterbitkan pada tahun 2007. Novel ini mengajak pembaca menyelami dunia paling personal penduduk Afghanistan dan memberikan inspirasi kepada pembaca bahwa perang dan segala bentuk penindasan tidak akan pernah menghilangkan semangat menuju kebebasan. Hosseini masuk 100 tokoh paling berpengaruh di dunia pada 2008 atas pengaruh besar pada dunia kesusasteraan dari majalah Time (Time, 2008).

Sebagai seorang penulis pria Afghanistan beretnis Pashtun 9 , Hosseini lebih mudah menceritakan kisah-kisah pilu dalam bentuk tertulis. Keberanian Hosseini bersuara telah

\footnotetext{
8 Dalam "Tentang Penulis" di novel kedua Hosseini A Thousand Splendid Suns dan disarikan dari berbagai tulisan.

9 Penduduk beretnis Pashtun memiliki kesempatan untuk mengenyam bangku pendidikan dan mengakses dunia luar. Mereka memiliki kebebasan, wawasan, dan keberanian yang lebih dibandingkan etnis lainnya. Etnis Pashtun merupakan mayoritas dengan populasi mencapai $38 \%$ dari keseluruhan penduduk Afghanistan yang berjumlah sekitar 30 juta orang. Selain etnis Pashtun, terdapat pula etnis Tajik, Hazara, Uzbek, dan beberapa etnis minoritas dalam Saleem Ali dan M. Saleem Javed, 'Helping Hazaras in Pakistan and Afghanistan', National Geographic (online). Tautan: http://voices.nationalgeographic.com/ 2012/01/16/ hazara_afghanistan_pakistan/ diunduh pada 16 Februari 2016.
} 